\title{
頭頸部悪性腫瘍患者における抗腫暍免疫能の研究
}

— 白血球粘着阻止 (LAI) 試験による検索——

札幌医科大学耳鼠咽喉科学教室（主任：北浦昭克教授）

水見徹 夫

\section{ANTI-TUMOR IMMUNITY IN PATIENTS WITH HEAD AND NECK CANCER MEASURED BY LEUKOCYTE ADHERENCE INHIBITION TEST}

TETSUO HIMI, M. D.

Department of Otolaryngology, Sapporo Medical College, Sapporo

The Leukocyte Adherence Inhibition (LAI) test was used to study anti-tumor immunity in patients with head and neck squamous cell carcinoma. 25.9 percent of the patients with laryngeal cancer ( 7 of 27 ) and 33.3 percent of the patients with maxillary cancer ( 6 of 18) had positive LAI responses to soluble extract from the same type tumor.

LAI responses were demonstrated in KLH sensitized mice peritoneal exudate mononuclear cells and human peripheral mononuclear cells.

The serum blocking factor (B. F.) was not detected in any LAI reactive patients with laryngeal and maxillary cancer. B. F. was measured by the inhibition rate of LAI responses of KLH-sensitized mononuclear cells. The lower reactivity of LAI responses and the higher percentage of the B. F. positive rate were shown in patients at a more advanced clinical stage.

To elucidate the nature of B.F., serum immune complexes (I. C.) were investigated by the anti-C3 solid phase ELISA. 20.7 percent of the patients with laryngeal cancer ( 6 of 29) and 31.3 percent of the patients with maxillary cancer ( 5 of 16) had positive serum I. C.. Similary, patients at a more advanced clinical stage had higher positive rates of serum I.C.. I. C.s in patients with positive B.F. were significantly higher than in those with negative B.F.. This suggests that serum B. F. is related to serum I. C..

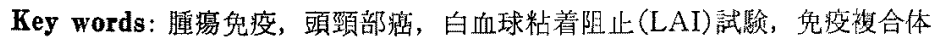

A88-0463-94362

\section{はじめに}

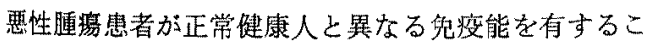
とは古くから指摘されており，その免度能の检索は，腥 湯抗原特異的なもの，非特哄的なものの両面からなされ てきている.近年はそれらを瘦の診断，臨床経過との対 比, 予後判定のパラメーターなどへ応用する可能性が検 討されている. 全身的な免疫能の检索には，担癌患者の 血球，特にリンバ球，マクロファージ，単球等の数的，
機能的变化, 担湾照者血清中出現, 消退する種々の因 子について検討されてきた.白血球粘着阻止 (Leukocyte Adherence Inhibition: LAI) 試験は，これらの全身的 な兒疫能の检索方法の一つであり，担癌宿主の単核細胞 (mononuclear cell) が隀瘍抗原化感作されている場合, 再度腄㻛抗原と反応することにより，その単核細胞のガ ラス面への粘着能が阻止される現集を利用したすのであ $ろ^{1)}$.この LAI 試験が，他の 全身的な免疫能検索の方 
法論と異なる点は，どの腫墪抽出抗原に対して屯粘着能 低下反応が括こるのでなく，抗原の種類に特徵的飞高い 反応を示すという点である.

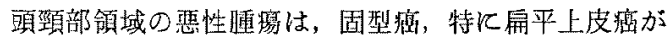

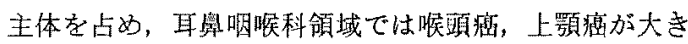

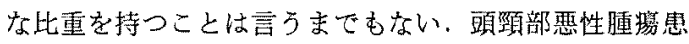

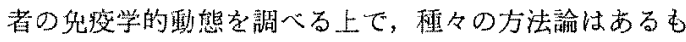

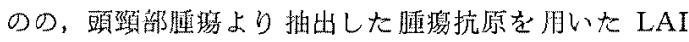

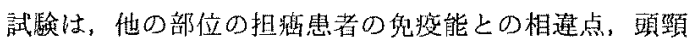

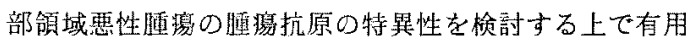
といえる。

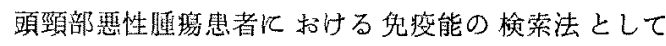

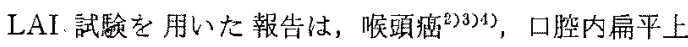

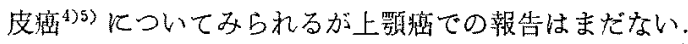

担堭㭧者では LAI 反応飞みられるような抗原特異的 な免疫反応を扰こす一方，担癌患者の血清中に，この LAI 反応を抑制する因子（LAI 阻止因子）が出現する ことが報告されて㧍り，病期の進行した症例には高率に 出現するとされている ${ }^{126)}$.

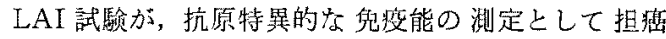
患者への応用が可能であるのみならず，この LAI 阻止 因子もまた担䍃患者の免疫能を示す一つのパラメーター と考えられ，知床経過との関連性と和いて重要な情報と なりうる。

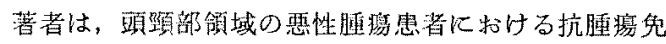
疫能を检索する目的で，頍頸部扁平上皮治より抽出した

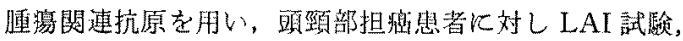
㧍よび Keyhole Limpet Hemocyanin ( $\mathrm{KLH}$ )を朋い た LAI 反応飞招ける LAI 阻止因子を検索し, 更にこ の LAI 阻止因子と関連性の深いとされる免疫被合体老， 抗C3 固相ELISA 法に上り測定し， その閒連を㭘討し たので報告する。

\section{対象および方法}

1. 好家

当科外来考受搒し，生検，手術捅出飞上り租織学的飞

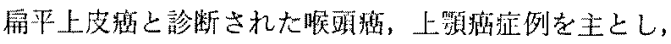

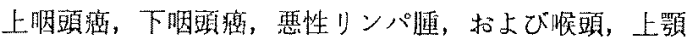
洞良性疾患症例屯执姑て模索の対象とした，病期分類

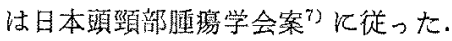

2. 随璄関通抗原の分離

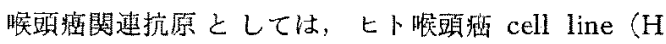
Ep \#2）を，上影瘦関連抗原としては，手術時に得られ

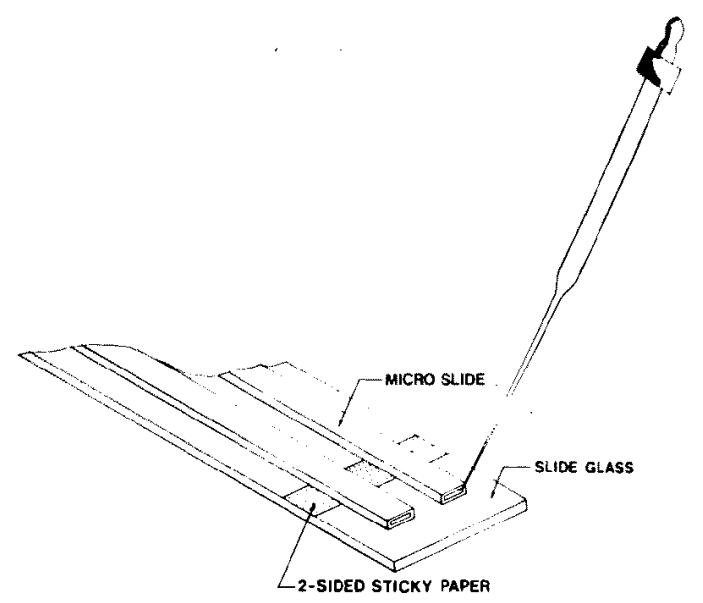

図 1 マイクロスライド法による LAI 試験

た腫榢組織より抽出したものを用いたすなわち $\mathrm{H} \mathrm{Ep}$ 抽は培養後，リン酸緩衝食塩水 (phosphate buffered saline: PBS) そて洗浄した後に，細胞沈渣の 5 倍量の PBS を加元, 再浮遊させた後, teflon homogenizer K てホモジナイズし，20000g 30分遠沈し，その上清分画

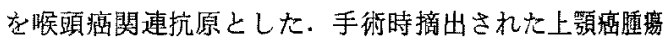
組織仙，冷却した PBS 内でよく洗浄し，脂肪織，觏死 組織を除去した後，八サミにて細切し，上記と同様飞 5 倍量のPBS を加えホモジナイズし 20000g 30分遠计後

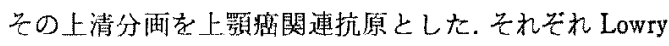
法8)にてタンパク浱度を測定し，使用時まで $-80^{\circ} \mathrm{CK}$ 湅結保存した.

\section{3. マイクロスライド法による LAI 試験}

Yonemoto" 9 方法を改变して用いた，士な⿰力口。 〈脱脂洗浄した内径 $0.3 \mathrm{~mm} \times 4.0 \mathrm{~mm}$ のマイクロスラ イド（Vitro Dynamic 社）をスライドグラスに両面粘 着テープを用いて固定し，オートクレープにて隇菌の

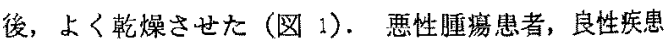
患者, 招上び正常健康人上りへパリン加採血汇て末梢血 を採取した，単核細胞分画は Ficoll-Conray 比重遠心法 $(\mathrm{d}=1.078)$ 老用い分離し，単核細胞層を採取し PBS Kて 3 回洗浄した後 RPMI 1640培羕液 (Gibco 社) K て $3.0 \times 10^{6} / \mathrm{m} l$ 亿調整した. 前述した腫演抽出抗原は, タンパク濃度 $0.2 \mathrm{mg} / \mathrm{ml}$ 江調整した. 末梢血より得た 単核細胞浮遊夜 $50 \mu l$ 之抽出抗原液 $50 \mu l$ を, ま大祄照 として RPMI 1640 培羡液 $50 \mu l$ をそれぞれ加方よく振 酮しながら $37^{\circ} \mathrm{C}$ 30分 インキュベーションした イン 
キュベーション終了後，マイクロスライドに抽出抗原一 单核細胞混合液を注入し，水平滘設置したスライドグラ ス支持台炑上面，すなわらマイクロスライド接着面を下 Kして, $5 \% \mathrm{CO}_{2}$ インキュベーターにて $37^{\circ} \mathrm{C} 1$ 時間 インキュベーションした. その後, 注意深く反枟し，さ ら飞 $37^{\circ} \mathrm{C} 1$ 時間インキュベーションを行った。付着細 胞はマイクロスライドの上面にとどまり，非付着細狍は 下面飞落下する。顕徽鏡下同一視野飞て，上面（付着細 胞)の細胞数と下面（非付着細胞）の細胞数をそれぞれ 4 視野飞つき算定した. 下記の式にて 付着率（\% Adherence: \% Ad) 和よび付着指数 (Adherence Index: A.I.) を求め，正常健康人対照例では全例付着指数 13 以下でることより，付着指数 13 以上の症例を腫瘍抗 原江対する LAI 試験陽性例とした。

付着率 (\% Adherence: \% Ad)

$$
=\frac{\text { 付着細胞数 }}{\text { 付着細胞数十韭付着細胞数 }} \times 100
$$

付着指数 (Adherence Index: A. I.)

$$
=\frac{\text { 対照付着率一腫境抗原添加付着率 }}{\text { 対照付着率 }} \times 100
$$

4. ガラスチュープ法による LAI 試験

Grosser and Thomson ${ }^{10)}$ の方法に隻じた.すなわら 末梢血単核細胞分画を前述と同様の方法にて 採取し， その浮避液 $\left(1 \times 10^{7} / \mathrm{m} l\right) \quad 0.1 \mathrm{~m} l$ 上抗原溶液 $0.1 \mathrm{~m} l$, RPMI 1640 培養液 $0.3 \mathrm{~m} l$ を脱脂, 隇菌したレイトン 培着試験管（空寸法 $11 \mathrm{~mm} \times 38 \mathrm{~mm}$, Weaton 社) $k$, 試験管培善面全体を被うように加兑，柽く振温した後， 試験管専用ラック（Weaton 社）飞固定した。対照とし て抗原溶液のかわり R RPMI 1640 培䈍液 $0.1 \mathrm{~m} l$ を用 いた，試駼管を水平份設置し， $37^{\circ} \mathrm{C} 2$ 時間 $5 \% \mathrm{CO}_{2}$ インキュベーターにてインキュベーションした.インキ ニベーション終了後, 専用ラックを静加飞垂直飞立て, 管底煌下した非付着細胞をパスッールピペットにて採 取し，Hemolizer（エルマ光学）にて赤血球を溶血させ た後, コールターカゥンター（エルマ光学 Model ACM 501）Kて非付着細胞数を算定したああらかでめ加えた 全体の細胞数を同様の操作でコールターカウンターにて 算定し，前述の式にて付着指数を算出した。

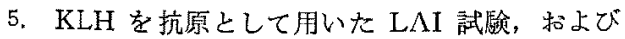

LAI 阻止因子の椧出

KLH の精製は Garvey ${ }^{11)}$ の方法に従った.すなわち KLH (Calbiochemie 社) \& PBS Kて十分K透析し硫
安を除去し, 沪紙 (東洋 paper filter No. 2) 飞て沪過 した後，78,000g 75分遠沈し，得られた沈渣江生理食塩 水孝加光再溶解した，上く䉕拌した後，透析特上び遠沈 をくり返し， $78,000 \mathrm{~g} 2$ 時間遠沈を行い, 生理食塩水に て䇛溶解後 Lowry 法にてタンパク湍度を測定し、ミリ ポアフィルター(pore size $0.45 \mu$ ) 飞て沪過滅菌し使用 時委で $-80^{\circ} \mathrm{C}$ 湅結保存した。

$\mathrm{KLH}$ 感作マウス腹腔単核細胞は, 以下の方法飞て採 取した. BALB/c マウス腹胵内一精整 KLH 0.1 mg を 投与し，3\%チオグリコレート（ニッスイ）飞て腹脭単

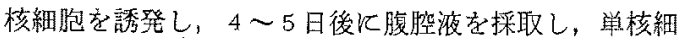
胞を分娟しPBS にて洗浄した後に使用した。

KLHの七トに対する感作法々，皮内テストとして行 いKLH 感作七ト単核細胞を得た。 KLH 度内テス卜 は，奥田ら ${ }^{12)}$ の方法に準して行った。すなわ力，減菌 精製 $\mathrm{KLH}$ 正常健康人の上腕伸側へ $0.1 \mathrm{mg}$ 皮下注射

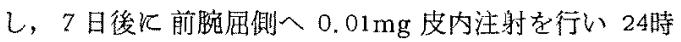
閲後に判定し $10 \mathrm{~mm}$ 以上の発赤硬結者認め大場合を皮 内テスト陽性とした，皮内テスト陽性，感作成立を確認 した後，ヘパリン加採血浮て末梢血を採职し，比重遠心 法飞て単核細胞分画老得, これを $\mathrm{KLH}$ 感作単核細胞 として用いた。

$\mathrm{KLH}$ 抗原とした LAI 試験は，ガラスチューブ法 を用い，この際炕加える KLH 抗原量は $50 \mu \mathrm{g} / 10^{6}$ cell の濃度とした。

担瘦患者血清中の LAI 阻止因子の検出は, 嗹焬抗原

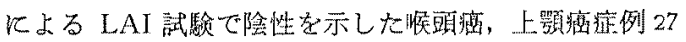
例を対象として㭘索した。すなっち，LAI 試騟陰性担

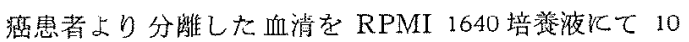
倍化希积し，乙の希釈血清と KLH 感作正常健康人より 分離した単核細胞 $\left(1.0 \times 10^{7} / \mathrm{m} l\right)$ 等量加元, 振盜さ 世度がら $37^{\circ} \mathrm{C} 1$ 時間インキュベーションを行った。 ンキュベーション終了後, 血清処理後単核細胞を PBS にて 2 回洗沵し，再浮遊させた．次にこの単核細胞を用 いて，精整 KLH 学抗原とし，ガラスチューブ法にて LAI 試频を行った. 対照としては正常徤康人より得た 血清を用いた，以下の式炕て阻止指数 (Blocking Index: B. I.) を求め，正常血清では阻止指数 0.7 以下であるこ と上り阻止指数 0.2 以上の症例赏, 血清中の LAI 阻止 因子陽性と判定した。
A : KLH 加非付着細胞数
B：対照非付着細胞数 
非付着指数 (Non Adherence Index: NAI)

$$
=\frac{\mathrm{A}-\mathrm{B}}{\mathrm{B}}
$$

阻止指数 (Blocking Index: B. I.)

$$
=1-\frac{\text { 担瘦患者血清処理後 NAI }}{\text { 正常健康人血清処理後 NAI }}
$$

6. 抗 C3 固相 ELISA 法学用いた 血清中兔疫被合体 の模出

血清中兔痖複合体 (Immune Complex: I. C.) の涀

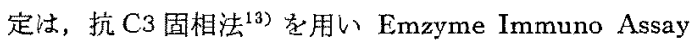
にて测定した。熱凝集ヒト IgG (Heat Aggregated Human IgG: AHG) は, Cohn Fraction II ヒト IgG (Miles Laboratorie 社) $63^{\circ} \mathrm{C}$ 20分 加熱し， 1, 500g 15分遠沈し，その上清分画とした．抗 $\mathrm{C} 3 \mathrm{~F}\left(\mathrm{ab}^{\prime}\right)_{2}$ 分画 （Cappel 社）を $0.01 \mathrm{M}$ 炭酸ナトリウム緩衝液（pH 9.6） にて 100倍希釈し，96穴マイクロプレート（Dynatech 社：M-129A）の各ウェルK $100 \mu \mathrm{l}$ ずつ入れ $4^{\circ} \mathrm{C}$ 一且 夜インキュベーションし，プレート上へコーティングを 行った. 各ウェルに 2\%牛血清アルブミン (Bovine Serum Albmin: BSA)-PBS-Tween 20 t2 $200 \mu l$ 入れ, 室温にて30分以上インキュベーションの後, プレートの 水分を十分飞きり，使用時まで $-30^{\circ} \mathrm{C}$ 飞保存した.

AHGのタンパク濃度を Bio-Rad Protein Assay Kit ${ }^{14 \text { 入 }}$ そて測定し, PBS-Tween 20 飞て AHG の各希歌倍数 溶液を作製し，それぞれに補体（C3）源として正常人新 鮮血清を等量加え $37^{\circ} \mathrm{C} 15$ 分インキュベーションした. AHG-C3 複合体溶液を最終 10倍希积となるよう $1 \%$ BSA-PBS-Tween 20-EDTA (0.01M)を加光標準曲線 作製使用した。

担癌患者血消, 括よび対照正常健康人血清を同㥞飞 $1 \%$ BSA-PBS-Tween 20-EDTA $(0.01 \mathrm{M}) k \tau 10$ 倍 希瑶し，その $100 \mu l$ をれぞれ各立ルル入れ $37^{\circ} \mathrm{C}$ 1 時間 インキュベーションした. PBS-Tween 20 にて 3 回洗浄後, 500倍希鄱アルカリフォスファターゼ標識 抗七ト IgG (KPL 社) を 100 $\mu$ 各ウェルに入れ， $37^{\circ} \mathrm{C}$ 1 時間インキュベーションを行った. 3 回 洗浄後, $\mathrm{MgCl}_{2}-0.05 \mathrm{M}$ 炭酸ナトリウム䌅衝液 ( $\mathrm{pH}$ 9.8) 飞て溶 解した $\mathrm{p}$-ニトロフェニルリン酸 (片山化学) $(2 \mathrm{mg} / \mathrm{m} l$ ) を $100 \mu \mathrm{l}$ 各ウェルK入れ $37^{\circ} \mathrm{C} 3$ 時間反応させ， 2 波長 マイクロプレート比色計（コロナ MTP-12）を用い 405 $\mathrm{nm}$ 飞て比色貺定した. 先飞作製した各种系列の AHG-C3 複合体溶液も，同様の操作を行い標準曲線（圆

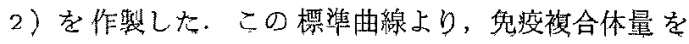

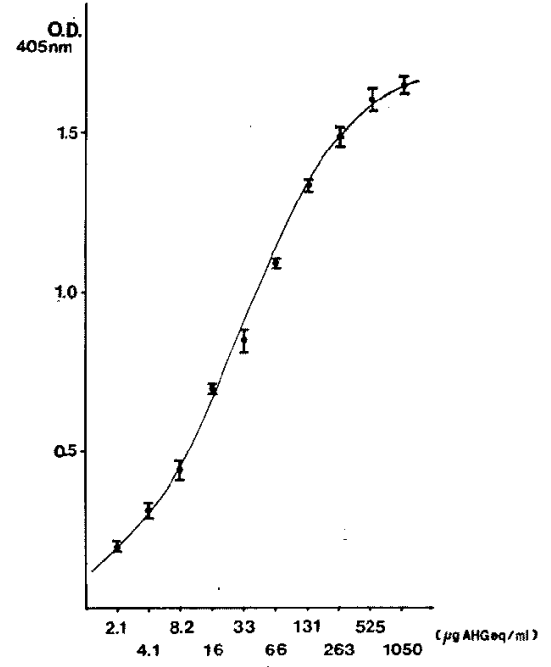

図 2 抗 C3 固相 ELISA 法に上る免疫複 合体の標笽曲線

AHG K換算して算出した．対照正常踺康人血清で， $1.32 \pm 0.79 \mu \mathrm{g} \mathrm{AHG} \mathrm{eq} / \mathrm{m} l \quad(\mathrm{n}=20)$ であり, $3 \mu \mathrm{g} \mathrm{AHG}$ $\mathrm{eq} / \mathrm{m} l$ 以上を血清中兔疫複合体陽性例とした。

7. 血清 Carcino Embryonic Antigen (CEA) の视 定

Roche 社の CEA-EIA キット ${ }^{15)}$ を用いて測定を行 い, $2.5 \mathrm{ng} / \mathrm{ml}$ 以上を血清 CEA 陽性例と判定した。

結果

1. 睡瑒抽出抗原を用いたマイクロスライド法 LAI 試験

咲頭癌関連抗原を用いた LAI 試験の結果を図 3 亿示

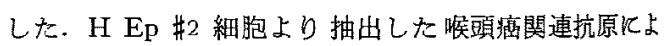
る LAI 試験では, 対照正常健康人群で, 付着指数 3.22 \pm 3.19 であった，喉頭瘦新鮮例 27 例では，付著指数 $8.50 \pm 7.96$ 之対照佂比し高値を示し, LAI 就駼陽性率 は 25.9\%(7/27)であった。一方，啒頭良性疾患群で は，付着指数 $5.66 \pm 3.05$ であり，5例のうち，付着指

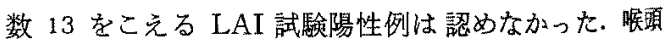

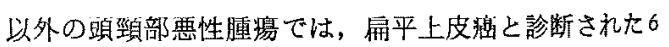
症例で, 付着指数 $10.00 \pm 3.85$ を示し, 搌顽癌症例と同 様の高值を示した。また, その LAI 試験陽性率は 16.7 $\%$ （1/6）であった（表 1).

上顎癌組織上りの抽出抗原を用いた LAI 試剩の結果 


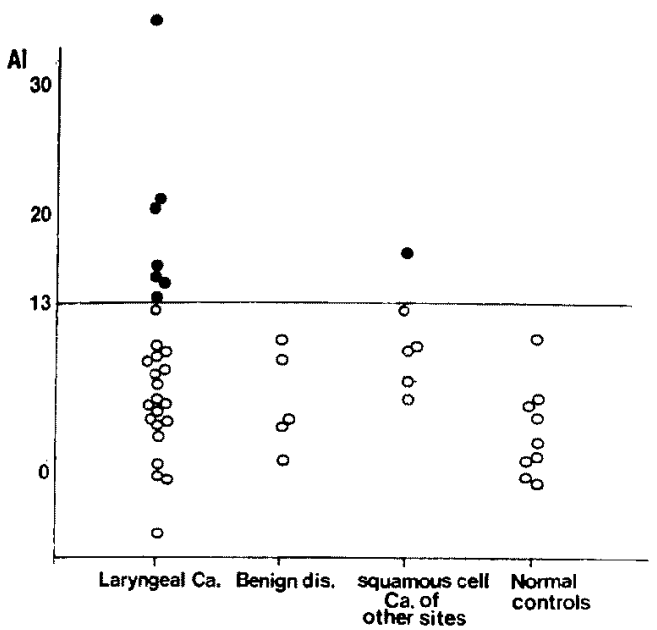

図 3 喉頭癌抽出抗原を用いた LAI 試験 (O LAI 試験陽性，○ LAI 試験㓌性)

を図4K示した．対照正常健康人群では，付着指数 4.10 \pm 5.33 であった，上顎瘦症例では，付着指数 $10.03 \pm$ 8.79 と対照飞比し高值を示し，LAI 試駼陽性率は 33.3 $\%(6 / 18)$ でった. 上顎洞主性疾患症例では，付着指

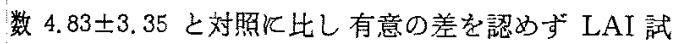
験陽性例を認めなかった，噍豆癌関連抗原を用いた時之 同粎に, 上顎癌関連抗原使用時毛，他の頭頸部扁平上皮 癌症例では, 付违指数 $10.25 \pm 5.64$ と高值を示し, LAI 試駼陽性率は $16.7 \%(1 / 6)$ であった. 舆腔原発悪性り ソパ迗の 2 症例では，付着指数 $5.50 \pm 3.00$ であり，い ずれす LAI 試驗陰性であった（表 1)。

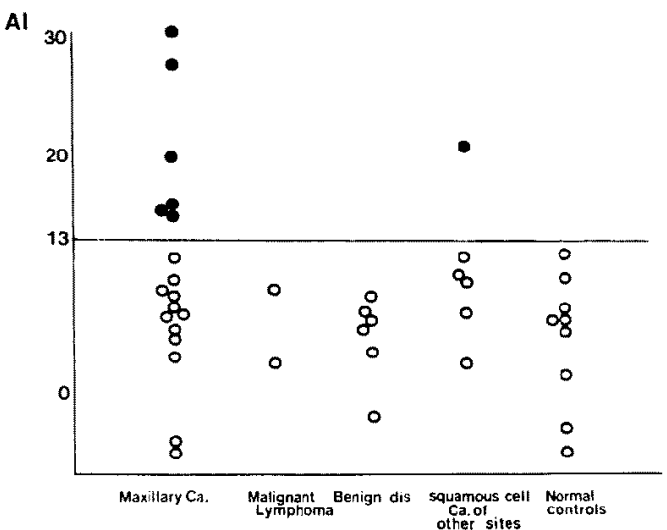

図 4 上顎筫抽出抗原を用いた LAI 試倹 (○ LAI 試験陽性， ○ LAI 試駼除性)

臨床病期別に啹頭癌症例を分類し检討を加えた結果， 病期 I， II 期の早期例ては 25.0\% (2/8) K LAI 試驗 陽性例を認め，II期では，36.4\% (4/11) と最も高い陽 性率示し，病期の谁行したV期では 12.5\%(1/8) と 陽性率の低下を認め大，手術治療後，ちるW心放射線治

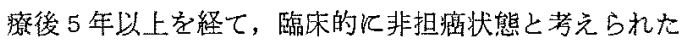
3例は，いずれあ LAI 試験陰性であった（表 2).

\section{KLH を抗原として用いた LAI 試験}

KLHにて感作された マウスより採取した腹腔単核細 胞は，KLHの添加により，その粘着能が低下し LAI 反 応の括こることが認められた，LAI反応の経時的变化 をみると，感作後 2 週目飞付着指数が最高值をとり，4

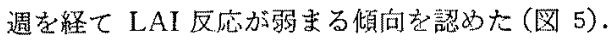

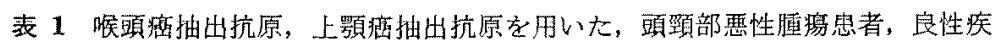
患患者における LAI 試験

\begin{tabular}{|c|c|c|c|c|}
\hline Tumor extract & \multicolumn{2}{|c|}{ Clinical diagnosis } & $\begin{array}{l}\text { Adherence Index } \\
\text { mean } \pm S D\end{array}$ & $\begin{array}{c}\text { Positive rate } \\
(\%)\end{array}$ \\
\hline \multirow[t]{4}{*}{ Laryngeal $\mathrm{Ca}$. } & Laryngeal $\mathrm{Ca}$. & $(n=27)$ & $* 8.50 \pm 7.96$ & $25.9(7 / 27)$ \\
\hline & Benign disease of Lary & $(\mathrm{n}=5)$ & $5.66 \pm 3.05$ & $0 \quad(0 / 5)$ \\
\hline & Squamous cell $\mathrm{Ca}$. of o & r sites $(n=6)$ & $* * 10.00 \pm 3.85$ & $16.7(1 / 6)$ \\
\hline & Normal controls & $(n=9)$ & $3.22 \pm 3.19$ & $0 \quad(0 / 9)$ \\
\hline \multirow[t]{5}{*}{ Maxillary $\mathrm{Ca}$. } & Maxillary $\mathrm{Ca}$. & $(n=18)$ & $*_{10.03 \pm 8.75}$ & $33.3(6 / 18)$ \\
\hline & Malignant Lymphoma & $(n=2)$ & $5.50 \pm 3.00$ & $0 \quad(0 / 2)$ \\
\hline & Benign disease of Max & ry sinus $(n=6)$ & $4.83 \pm 3.35$ & $0 \quad(0 / 6)$ \\
\hline & Squamous cell $\mathrm{Ca}$. of o & er sites $(n=6)$ & $* 10.25 \pm 5.64$ & $16.7(1 / 6)$ \\
\hline & Normal controls & $(n=9)$ & $4.10 \pm 5.53$ & $0 \quad(0 / 9)$ \\
\hline
\end{tabular}

$$
* \mathrm{p}<0.1 \quad * * \mathrm{p}<0.001
$$




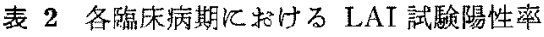

\begin{tabular}{cccc}
\hline Clinical stage & No. tested & Positive & $\%$ Positive \\
\hline I, II & 8 & 2 & $25.0 \%$ \\
III & 11 & 4 & $36.4 \%$ \\
V Advanced & 8 & 1 & $12.5 \%$ \\
\hline Tumor free & 3 & 0 & $0 \%$ \\
\hline
\end{tabular}

次に，抗原濃度と LAI 反応との関逨をみると，添加 した KLH の酮度の上昇とともに，付着指数が上䒜し， $50 \mu \mathrm{g} / 10^{6}$ cell 以上ではプラトーを形成した.しかし; 牛血清アルブミンの添加では，その裖度の上界にても LAI 反応は括こらず, KLH 感作マウス腹腔単核細胞で は，KLHに特翼的に LAI 反応の特こることが認めら れた (図 6).

$\mathrm{KLH}$ 皮内テストにより感作成立の確㑇されたヒト末 梢血単模緗胞と KLH 轨原との LAI 反応屯, 、ウスと ほほ同じパーンをとり，感作後 2 週目にかけ付着指数

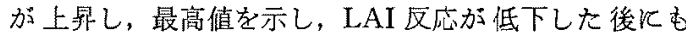
再感作を行うことで再び LAI 反応の增強を認めた。す なわち，上卜の場合飞も，抗原感作末梢血単核細胞方， その抗原との 免度灾答飞て 粘着能が低下し，LAI 反応 の特こることが認められた（図 7).

3. LAI 阻止因子の検出

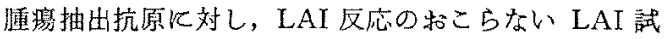

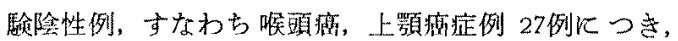
血清中 LAI 阻止因子の検出老行った。 LAI 反阻止試 験には，KLHによる LAI 試験陽性者の LAI 反忘を 用い，担密患者血清処理後の LAI 反心㦄の阻止率を检索 Lた.

喉頭癌, 上顎密㭧者血清処理後の付着指数之対照正常 血清処理後の付着指数を図 8 K示した。䛗床病期别にみ る己, 病期 I，II 期の早期の喉㖽瘦症例飞比较して， III， $\mathbb{N}$ 期の進行例の担瘦患者血清好理例では, 藷しく付着指 数が低下し，LAI 原応が強く排制されることが判明し た. 刘照群では LAI 区応の強い抑制は認めなかった (図 8).

阻止指数が 0.7 以上学示し, 血清中 LAI 阻止因子が

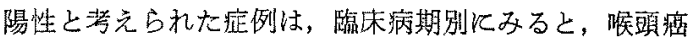
症例で， I， II 期で $0 \%(0 / 6) ， \mathbb{I I I}$ 期 33.3\% (2/6)，

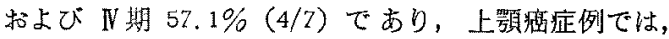
III期 50.0\% (1/2)，W期杖よび進行症例ては 50.0\%

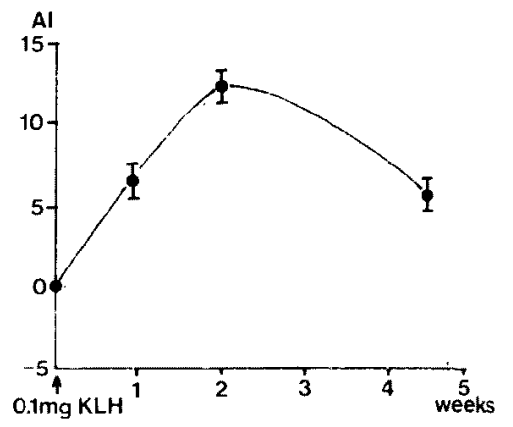

図 $5 \mathrm{KLH}$ 感作マウス腹腔単核細胞を用 いた LAI 反店の経時的变化

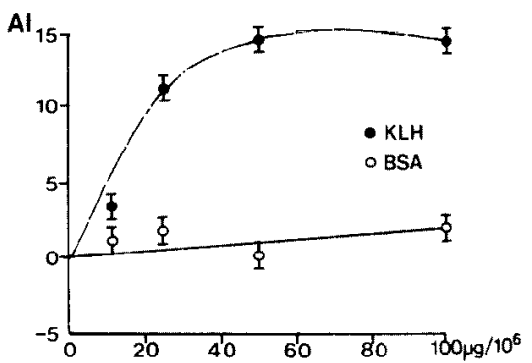

図 $6 \mathrm{KLH}$ 感作マウス腹腔単核細绚を用 いた LAI反応の Dose-Response Curve（感作後 14日目)

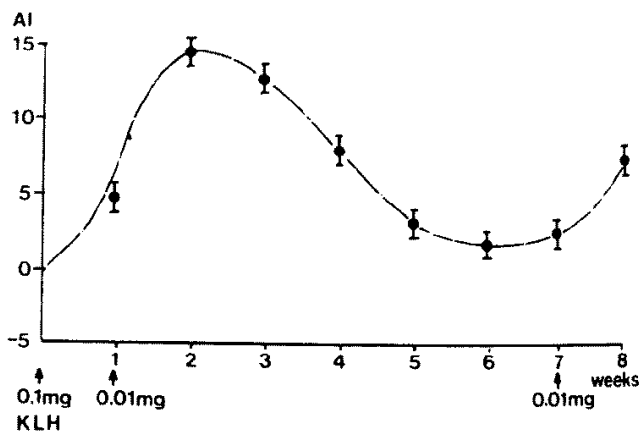

図 $7 \mathrm{KKH}$ 感作ヒト末梢血単核細胞飞就 ける LAI 反応の経時的变化

(3/6)であった.すなわち, 病期の進行飞伴い, LAI 阻 止因子の陽性率の上昇を認めた（表 3 ）.

4. 担癌患者血清中兔疫複合体と LAI 阻止因子

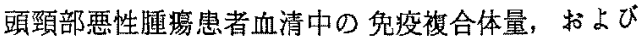
$3 \mu \mathrm{g} \mathrm{AHG} \mathrm{eq/ml}$ 以上を示高免疫複合体陽性例梳，搌 

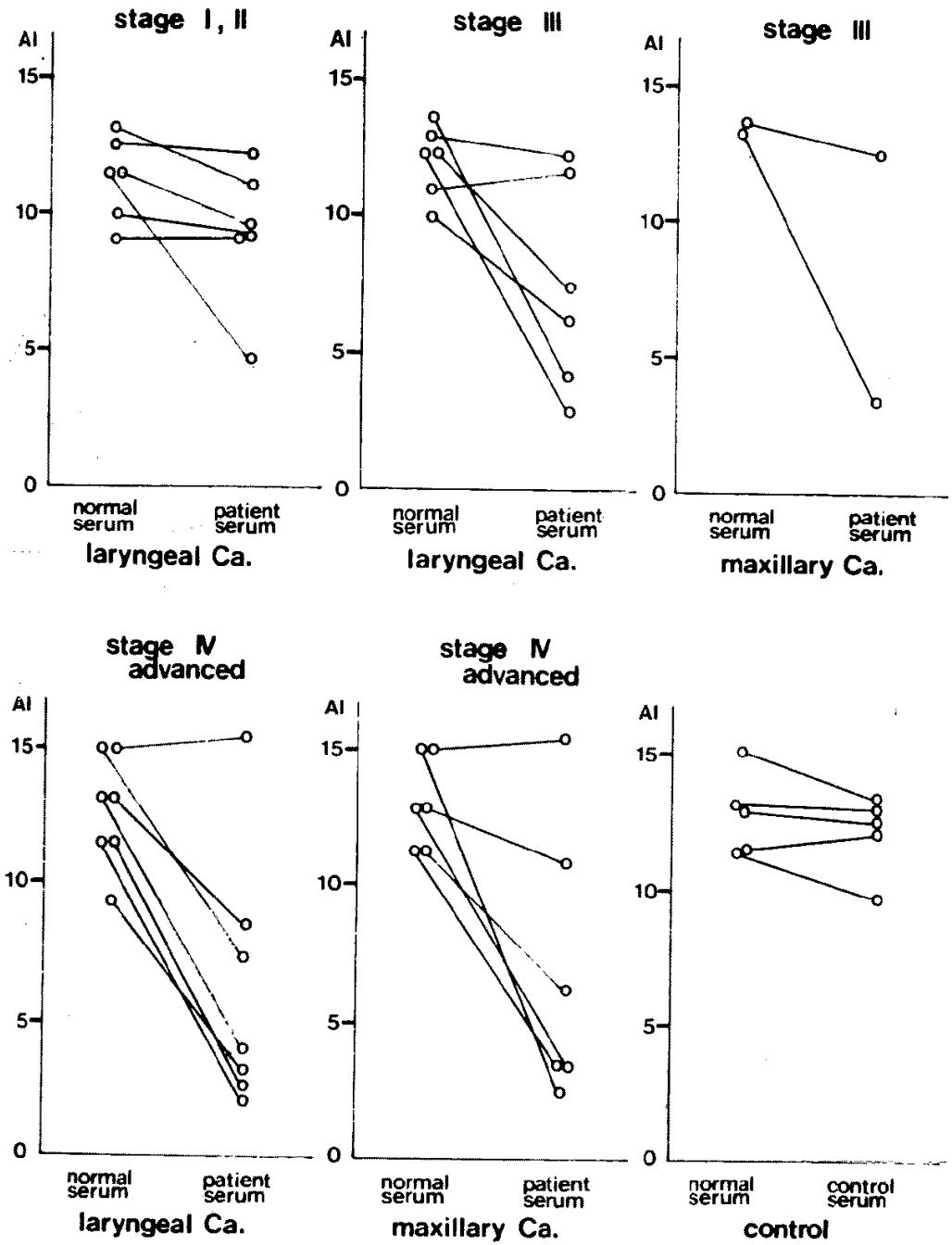

图 8 啹頭癌, 上顎瘦患者血清処理による KLH-LAI 反応の变化

頭癌症例 29例では，それそれ 3.22士5.01 $\mathrm{g}$ g AHG eq/ $\mathrm{ml}, 20.7 \%$ (6/29) であった. 臨床病期分類では, I 期 $1.05 \pm 0.09 \mu \mathrm{g} \mathrm{AHG} \mathrm{eq} / \mathrm{ml}, 0 \%(0 / 4)$, II 期 $1.22 \pm 0.50$ $\mu \mathrm{g} \mathrm{AHG} \mathrm{eq} / \mathrm{m} l, 0 \%(0 / 5), \quad$ III ${ }_{\text {期 } 1.91 \pm 0.85 \mu \mathrm{g} \mathrm{AHG}}$

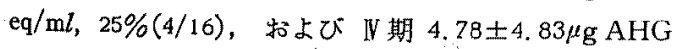
$\mathrm{eq} / \mathrm{ml}, 50 \%(2 / 4)$.であった。 上頡癌症例 16例では, 兔度複合体量，标上びその陽性例はそれぞれ2.19土1.94 $\mu \mathrm{g} \mathrm{AHG} \mathrm{eq} / \mathrm{m} l, 31.3 \%(5 / 16)$ であり, 臨床病期分類て 法, II 期 $1.87 \pm 1.16 \mu \mathrm{g} \mathrm{AHG} \mathrm{eq} / \mathrm{ml}, 28.6 \%(2 / 7), \mathrm{V}$ 期预よび進行例では $2.42 \pm 2.35 \mu \mathrm{g} \mathrm{AHG} \mathrm{eq} / \mathrm{m} l, 33.3 \%$

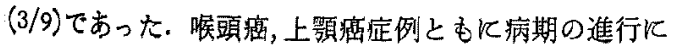

伴い免疫複合体量怙よびその陽性率の上昇がみられた。 他の頭頸部悪性迁富患者血清の免疫複合体量拉上び陽性 率は，下咽頭癌症例 $1.60 \pm 0.75 \mu \mathrm{g} \mathrm{AHG} \mathrm{eq} / \mathrm{ml}, 16.7 \%$ $(1 / 6)$, 上咽㽬瘦症例 $0.80 \pm 0.23 \mu \mathrm{g} \mathrm{AHG} \mathrm{eq} / \mathrm{ml}, 0 \%$ (0/5) 枋よび悪性リンバ腫症例では $1.12 \pm 0.42 \mu \mathrm{g} \mathrm{AHG}$ $\mathrm{eq} / \mathrm{m} l, 0 \%(0 / 13)$ であった (表 4$)$.

発症より長期経過観祭が可能であった症例につき LAI 阻止因子と免疫被合体量の变動をみると, 図 9 K 示した踇頭癌症例のごとく, 頸部枟移の出現とともに LAI 阻止因子 (阻止指数), 兔疫被合体量肪とも火上昇 する症例を経験した. 同時飞測定した CEA 值には変化 


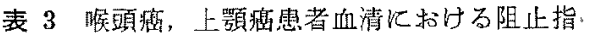
数(B.I.) 㕲よび LAI 阻止因子 (B.F.) 陽性率

\begin{tabular}{|c|c|c|c|c|}
\hline $\begin{array}{l}\text { Clinical } \\
\text { stage }\end{array}$ & $\begin{array}{l}\text { Clinical } \\
\text { diagnosis }\end{array}$ & $\begin{array}{c}* B . I . \\
\text { mean } \pm S D\end{array}$ & $\begin{array}{l}* * \text { B. F. } \\
\text { Positive }\end{array}$ & $\mathrm{c}(\%)$ \\
\hline $1, \mathbb{I}$ & $\begin{array}{l}\text { Laryngeal Ca. } \\
(\mathrm{n}=6)\end{array}$ & $0.20 \pm 0.20$ & 0 & $(0 / 6)$ \\
\hline \multirow[t]{3}{*}{ III } & $\begin{array}{l}\text { Laryngeal Ca. } \\
(\mathrm{n}=6)\end{array}$ & $0.39 \pm 0.36$ & 33.3 & $(2 / 6)$ \\
\hline & $\underset{(\mathrm{n}=2)}{\text { Maxillary Ca. }}$ & $0.42 \pm 0.34$ & 50.0 & $(1 / 2)$ \\
\hline & & $0.39 \pm 0.27$ & 37.5 & $(3 / 8)$ \\
\hline \multirow[t]{3}{*}{$\mathbb{N}$} & $\begin{array}{l}\text { Laryngeal Ca. } \\
(\mathrm{n}=7)\end{array}$ & $0.56 \pm 0.26$ & 57.1 & $(4 / 7)$ \\
\hline & $\begin{array}{l}\text { Maxillary Ca } \\
(n=6)\end{array}$ & $0.48 \pm 0.28$ & 50.0 & $(3 / 6)$ \\
\hline & & $0.52 \pm 0.26$ & 53.8 & $(7 / 13)$ \\
\hline
\end{tabular}

**B. F. Positive: B. I. $>0.7$

*B. I. : Blocking Index

**B. F. : Blocking Factor

表 4 頭頸部檼性腫湯患者における血清兔疫複 合体

\begin{tabular}{|c|c|c|}
\hline $\begin{array}{l}\text { Clinical } \\
\text { diagnosis }\end{array}$ & $\begin{array}{c}\text { Immune Complex } \\
\text { mean } \pm \mathrm{SD} \\
(\mu \mathrm{gAHGeq} / \mathrm{m} l)\end{array}$ & $\begin{array}{c}\text { Positive } \\
\text { rate }\end{array}$ \\
\hline $\begin{aligned} \text { Laryngeal Ca. } & (\mathrm{n}=29) \\
\text { stage } \text { I } & (\mathrm{n}=4) \\
\text { II } & (\mathrm{n}=5) \\
\text { II } & (\mathrm{n}=16) \\
\text { IV } & (\mathrm{n}=4)\end{aligned}$ & $\begin{array}{r}3.22 \pm 5.01 \\
1.05 \pm 0.09 \\
1.22 \pm 0.50 \\
* 1.91 \pm 0.85 \\
* * 4.78 \pm 4.83\end{array}$ & $\begin{array}{cl}20.7 & (6 / 29) \\
0 & (0 / 4) \\
0 & (0 / 5) \\
25.0 & (4 / 16) \\
50.0 & (2 / 4)\end{array}$ \\
\hline $\begin{array}{rr}\text { Maxillary Ca. } & (\mathrm{n}=16) \\
\text { stage III } & (\mathrm{n}=7) \\
\text { W } & (\mathrm{n}=9)\end{array}$ & $\begin{array}{r}*_{2.19} \pm 1.94 \\
1.87 \pm 1.16 \\
*_{2.43 \pm 2.35}\end{array}$ & $\begin{array}{ll}31.3 & (5 / 16) \\
28.6 & (2 / 7) \\
33.3 & (3 / 9)\end{array}$ \\
\hline $\begin{array}{l}\text { Hypopharyngeal } \\
\qquad \text { Ca. }(n=6)\end{array}$ & $1.60 \pm 0.75$ & $16.7(1 / 6)$ \\
\hline $\begin{array}{l}\text { Nasopharyngeal } \\
\qquad \mathrm{Ca}(n=5)\end{array}$ & $0.80 \pm 0.23$ & $(0 / 5)$ \\
\hline $\begin{array}{l}\text { Malignant Lymphoma } \\
\qquad(\mathbf{n}=13)\end{array}$ & $1.12 \pm 0.42$ & $(0 / 13)$ \\
\hline $\begin{array}{l}\text { Normal Controls } \\
\qquad(n=20)\end{array}$ & $1.32 \pm 0.79$ & - \\
\hline
\end{tabular}

$$
{ }^{*} \mathrm{p}<0.1 \quad{ }^{* *} \mathrm{p}<0,01 .
$$

\section{Case S.Y. $54 / \mathrm{M}$ 'T3 $\mathrm{N}_{1} \mathrm{Mo}_{0}$. Laryngeal $\mathrm{Ca}$}

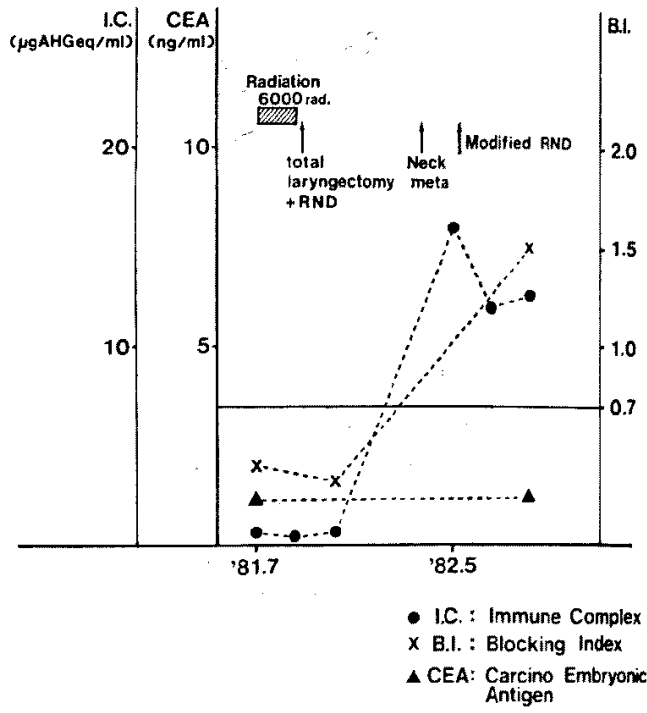

图 9 喉頭癌症例 (S.Y.) 飞和ける，阻止指 数, 血清免疫複合体, 沶上び澏胎沉杭原 (CEA) の变化と臨㦿経過

Case I.T. 64/M T3N2Mo Laryngeal Ca*

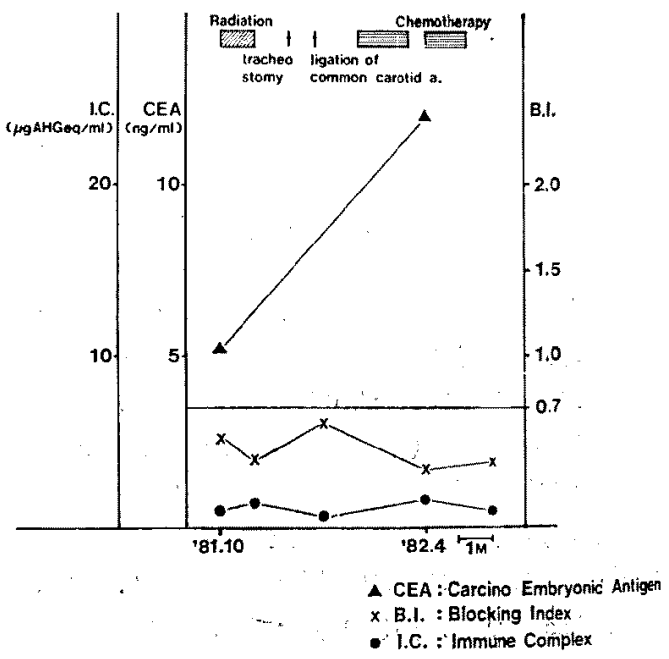

图 10 喉頭癌症例 (I. T.) 代おける阻正指 数, 血清免疫複合体; ‘肪よ゙癌胎児抗原 (CEA) の变化之䍉床経過 


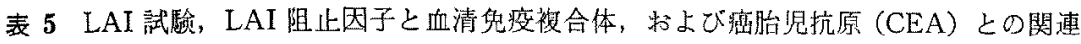

\begin{tabular}{llccccc}
\hline & LAI & B. F. & $\begin{array}{c}\text { I. C } \\
\text { mean } \pm \text { SD } \\
(\mu \mathrm{gAHGeq} / \mathrm{m} l)\end{array}$ & $\begin{array}{c}\text { Positive } \\
\text { rate }\end{array}$ & $\begin{array}{c}\text { CEA } \\
\text { mean } \pm \text { SD } \\
(\mathrm{ng} / \mathrm{m} l)\end{array}$ & $\begin{array}{c}\text { Positive } \\
\text { rate }\end{array}$ \\
\hline group A $(\mathrm{n}=8)$ & Positive & - & $1.58 \pm 1.04$ & $12.5 \%(1 / 8)$ & $3.29 \pm 3.95$ & $25.0 \%(2 / 8)$ \\
group B $(\mathrm{n}=7)$ & Negative & Negative & $2.27 \pm 1.15$ & $28.6 \%(2 / 7)$ & $1.23 \pm 1.18$ & $14.3 \%(1 / 7)$ \\
group C $(\mathrm{n}=6)$ & Negative & Positive & $6.15 \pm 4.26$ & $50.0 \%(3 / 6)$ & $2.60 \pm 2.66$ & $33.3 \%(2 / 6)$ \\
\hline
\end{tabular}

A: C $\quad p<0.025 \quad$ B:C $\quad p<0.1$

I. C. : Immune Complex LAI : Leukocyte Adherence inhibition B. F. : Blocking Factor

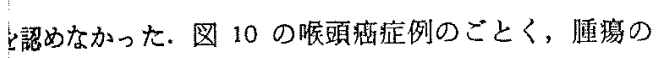
急激な增大とともに CEA 值が上昇し, LAI 阻止因子 阻止指数)，兔疫䙓合体量はともに低值にとどまり，变 七に之しい症例当経験した。

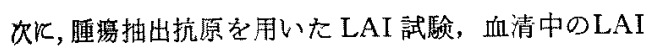
且止因子，免复袮合体，拉よび CEA の四者を同時飞检 得た症例飞つき, LAI 試験陽性群を A 群, LAI 試 渝陰性を示し血清 LAI 阻止因子も隆性を呈した群をB 羊，招よび LAI 試驗陰性加つ LAI 阻止因子陽性群を 群として比較検討した．A群の血清中免疫複合体は， l. $58 \pm 1.04 \mu \mathrm{g} \mathrm{AHG} \mathrm{eq} / \mathrm{m} l$ であり，血清中鬼疫複合体陽 生例㥫 $12.5 \%(1 / 8)$ であった，B群ではそれぞれ 2.27 $\pm 1.15 \mu \mathrm{g} \mathrm{AHG} \mathrm{eq} / \mathrm{ml}, 28.6 \%(2 / 7)$ ，C群では $6.15 \pm$ 4. $26 \mu \mathrm{g} \mathrm{AHG} \mathrm{eq} / \mathrm{m} l ， 50 \%(3 / 6)$ 之 LAI 阻止因子陽性 䬺で免疫複合体が氈值を示し，A群に比し有意（ $p<$ D.025）飞高い值を示した. 一方 CEA については，A 群で CEA 值 $3.29 \pm 3.95 \mathrm{ng} / \mathrm{ml}$ ，CEA 陽性率は 25.0 $\%(2 / 8) ，$ B群ではそれぞれ $1.23 \pm 1.18 \mathrm{ng} / \mathrm{ml}, 14.3 \%$ (1/7)，捻よびC群で沈 $2.60 \pm 2.26 \mathrm{ng} / \mathrm{ml}, 33.3 \%(2 / 6)$ であり各群に特に差を認めなかった（表 5).

\section{考察}

\section{1. 頭頸部担鹰患者の免疫動態}

担痁患者の免疫動態の検索としては，非特異的兒疫 能, carcino fetal antigen, 各種 isozymeなどね代表さ

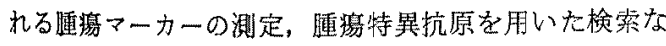

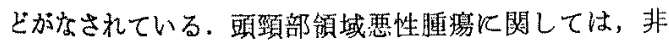
特巽的免度能の検索として，遅延型過敏反応学利用した 皮内テストの成樍 ${ }^{16)}$ ，Tリンパ球を主体とした末梢血リ

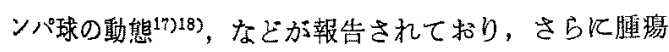
マーカーとしての carcino fetal antigen も実際に広く

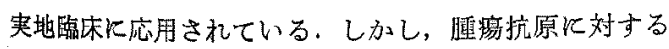

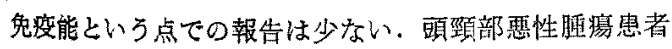

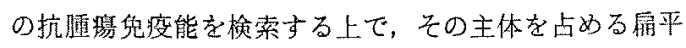
上皮瘦の腄場抽出抗原を用いた白血球粘着阻止 (LAI) 試䮖法，多くの有用な情報を提供してくれると考元られ

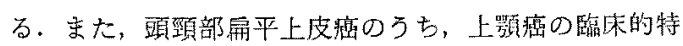

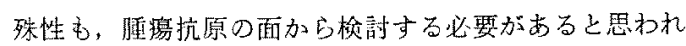

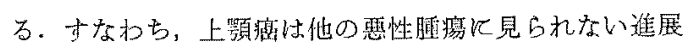

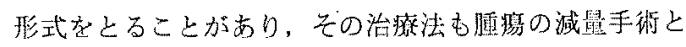

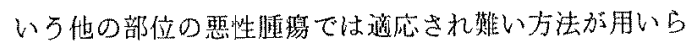

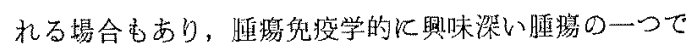
ある。このような上顎壆の兔疫学的特殊性を解く一つの

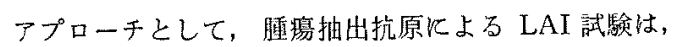
極めて有用な手段となり得ると考えられる。

2. 白血球粘着阻生 (LAI) 試騟について

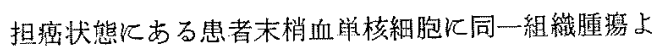
りの抽出抗原を作用させることにより，担癌患者草核稩 胞のガラス面への粘着能が低下する現象は1972年 Halliday ${ }^{1)}$ が報告し, 白血球粘着阻止 (LAI) 現象と呼ばれ ている、その後この LAI 反心の組織特巽性が注目され，

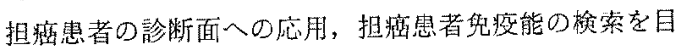
的として, 多くの施設でその意義や方法諭が检討されて

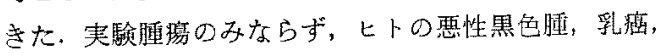

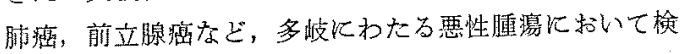
討され，それぞれの電場抽出抗原に特徽的な反応が認め られると報告されている(6)19120121).

LAI 試䮖は当初上り種々の方法部合教案されている。 Halliday の酦告した血球計算盤法》をはじめ，ガラス 千ューブ法9, マイクロプレート法22)，マイクロスライ ド法文，などである。このように手技が多岐にわたると， 方法諭による成結の差買汃問題亡なるが，これについて は1979年にコード化されたサンプルを各施設に送淤し， いずれの施設にても同一の結果が得られたことである

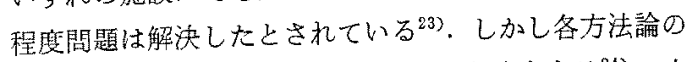
LAI 現象のメカニズムは異なるとの報告すある 
球語算盤法は手技にかなり熟練を要するため，再現性の 高い方法として，ガラスチニーブ法，マイクロスライド 法が考案された，著者むこの二者を用いて LAI 試験を 行った。ガラスチューブ法では，湘定に客観性を持たせ るため, 細胞数の算定を自動血球計算器にて行い，良好 な結果を得た. Yonemoto9 は同椂の考方方より、マイ クロスライド法に image analyzer を用い LAI 試験を 行い，臨床椟植レベルへの応用を示唆している.

LAI 反応のメカ二ズム决ていまだ不明な点が 多い. Halliday ${ }^{253}$ は感作Tリンバ球が抗原感作の後に リンホカイン様物質である Leukocyte Adherence Inhibition Factor (LAIF) を産生し白血球の粘着能を阻 止すると推定している，一方 Grosser ら ${ }^{26)}$ は抗原芯答 は monocyte でありその Fc receptor 上へ, 特異抗原 と cytophilic antibody の複合物肪結合することで粘着 能の低下加就きる考えている。マウスを用いた実驗で 恬，Myers $5^{27)}$ Kよれば，Tリンパ球，Bリンバ球の みでは LAI 反応㹥扎こらす、マタロフォージの関与が 必要であり LAIF の effector cell はマクロファージで あると報告している. Koppi ら ら $^{28}$ によれば Thy-1, Ly-1 を表面マ一カーに持つ細胞が LAIF を産生する としている.ヒトル関しては Powell b ${ }^{299}$, Tayler b 30) がそれぞれ LAI 反応には IgG Fc receptor 陽性 T リンパ球が必要であると報告している.

3. LAI 試験の問題点

LAI 試験の 問題点は, 反応の主体となる腫䓪抽出抗 原の均一性であり，この点は多く指摘されている ${ }^{31}$ 。抗 原抽出方法む $3 \mathrm{M} \mathrm{KCl}^{22)} \mathrm{PBS}^{1)}$ を用いるなと報告者に より異なり，抽出抗原により正常者に非特異的に LAI 反応を邨こす場合がある。これは抽出抗原があくまで粗 抗原であることに由来し，抽出物中に存在する組織適合 抗原, 免疫複合体, 正常組織抗原等が反応を修飾するこ とが十分に考えられる。上述のように LAI 試験には, まだ米解决の問題が残されているが，間便かつ短時間で

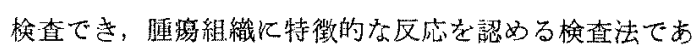
るという点を考之合わせると, 現時点に括ける睡演免疫 能の検索方法としては最屯有用なむのの一つに挙げられ る、現在さらに特買性を高めるため㮔々の工夫がなさ

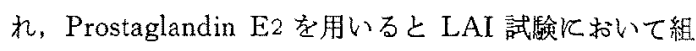
織型の特翼性が高まるとの報告がある゙22. また正常組織 抗原の混入をさけるため，腄湯 cell line を用いて良好 な成綪を得たとの報告もあり ${ }^{33334)}$, 著者む喉頭煌に対し

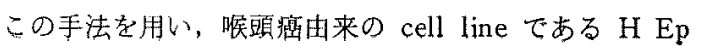

节2 を雨い LAI 試験を行った。

\section{LAI 試驗の頭頚部悪性腫惕への态用}

頭頸部悪性腫湯患者の免疫能の検索法として LAI 誠 䲗を用いた報告は少なく, 喉頭癌症例, 口腔内扁平上皮 瘦症例の報告がみられるのみで，上顎嗐症例についての 報告はみられず，著者の報告が最初といえる，LAI 誡

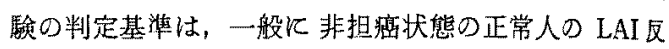
心を基準とし境界を定め，これを基㑥性，㓌性が判定

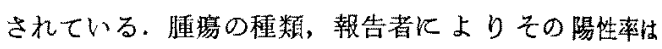
30〜 100\%とさまざまである。頭頸部領域では，㘈票 症例で Hasek $5^{3)} の 81.8 \%(18 / 22)$, Holan $b^{2)} の$ $51.7 \%(4 / 7)$, 口腔内扇平上皮癌症例では, 由井 $b^{5)}$ 95. 8\%(23/24) と LAI 試験陽性率の高い報告がみられ る. 一方, Vetto $5^{4)}$ は頭頸部㩔平上皮癌 111 例飞対し LAI 試験を行い，その陽性率は $32.4 \%(36 / 111)$ でっ たと報告している．今回の著者の成績は，喉頭鹰症例て $25.9 \%$ ，最も陽性率の高い病期 III 期て $36.4 \%$ でり,

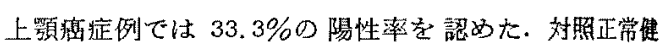
康人に比し，付着指数任高值をとるものの，LAI 陚歌隄 性率からは，Hasek ら，由井らの報告に比し低值をと り、Vetto らの報告に近いといえる。この要因は，使用 した腫瘍抽出抗原の抗原性が関与している可能性がある が，著者は担㾍患者血清中に出現する LAI 阻止因子の 関与が最も重要と考えている。すなわら，LAI 阻此子 の存在が LAI 試験の陽性率に大きく影留するため LAI

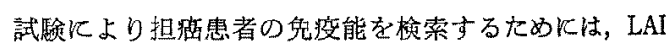
反応括よび LAI 阻止因子を同時飞検索する必要があり， どちらか一力のみでは抗腫诲免疫能を正確他握てきな いと考光られる。

5. LAI 阻止因子

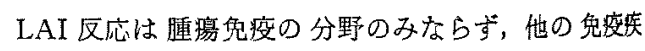
患への応用も試みられ，関節炎 ${ }^{36)}$, 膠原病 ${ }^{37)}$, 薬物了V

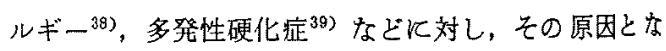
る抗原の検索等に LAI 試驗が応用されている。この意

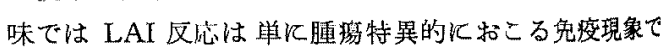
はなく，抗原感作状態にある単核細胞におこる一般的な 筧疫現象上考えられている。著者は KLHを抗原とし， KLH K感作されたマウス腹然単核細胞，上ト末梢血 単核細胞飞 LAI 反灾の秃こることを確かめ，患者血清 における LAI 阻止因子の检出に用いた，ヒトに和いて は遅延型過敏反応飞よる皮内テスト陽性者に，用いた抗 原に対し LAI 反岕の抗こることが報告されて初り， PPD を用いてッ反强陽性者の末梢血単核細胞て LAI反 
忘の括こること㣙，さら飞 DNCB 陽性者にも同様飞

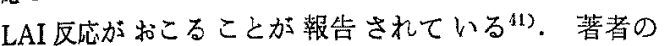
$\mathrm{KLH}$ を用いた $\mathrm{KLH}$ 皮内テスト陽性者で認められた LAI 反応も，上述の PPD D D CB の場合と同様の メカニズムにより同き括こされたものと考えられる、ツ 反陽性者を用いた LAI 試驗の場合, その陽性率江かな りのはららさがみられ，この点 KLH は抗原性が高く，皮 内注射のみて感作され，かつ人体に对し然害であり，LAI 反応を一定して引き招こすことが認められた。 また $\mathrm{KLH}$ 再感作Kてむ LAI 反応が認められた。この意味で LAI 反応のメカニズムの解析や, LAI 阻止因子の検出K KLH を用いた LAI 試験は有用と思われた。

担瘦患者血清中には種々の LAI 反応を修飾する因子 が出現することが知られている。 LAI 阻止因子のみな らず，LAI 反忘を特翼的に引き括こす Arming Factor, LAI 阻止現象を逆化阻止する Un-blocking Factor が存 在するとされる. Arming Factor Kついては Thomson $5^{26)}$ Kよれ活，嗹場関連抗原飞対する cytophilic antibody が抗原との複合物をつくり，これが非担癌正常人 の血球作用し，LAI 反応を抗こするのと考元ている。 Arming Factor 角い，担癌患者血清のみKて LAI 試 験の応用の試みもなされている35)43).

LAI 阻止因子は Halliday $5^{1)}$ が報告し，担癌生体 に和いては腄榢の增大江徒い LAI 反応を抑制する因子 が担毡生体血清中に出現することを認めた。 この LAI

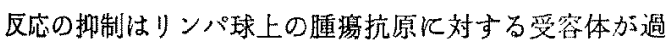
剩抗原によりブロックされるためと考光られた ${ }^{44)}$. ヒト

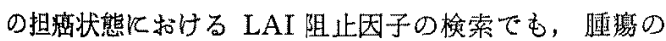
增大，病期の進行飞従い LAI 反応加低下し，担癌患者 血清中K LAI 阻止因子が高率に出現することが報告さ

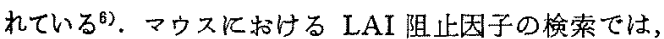
LAI 阻止因子陽性例で T細胞 サプレッサー活性の上昇 を認めたとされ(5)，また LAI 阻止因子は抗 I-J 抗体飞 てその活性が失われることより Major Histocompatibility Complex (MHC)のうち, 特に I-J subresion に より決定される抗原が関与していると報告されている 16). 特にこの因子はサプレッサーT細胞が 産生すると の報告むある. また, LAI 阻止因子と免疫被合体との関 連性を示唆する報告るみられる(7)。

6. LAI 阻止因子検出の意義

今回の LAI 試駼陰性を示した担癌患者血清中の LAI 阻止因子の検索ては，病期の進行した N 期, 進行癌症例 では LAI 試験陰性例の 半数以上K LAI 阻止因子の陽
性例を証め，腫陽抗原を用いた LAI 試䮖の除性化飞大 きく闋与していることを認めた。経過観祭し得た症例で は，再発，転移と之も火 LAI 阻止因子の血清中出現を

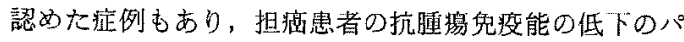
ラメーターとして, 阻止因子検出の有用性が示唆され た，LAI 阻止因子の検出には，常炈 LAI 反応陽性圭示 す系を持つ必要驾ある。今回著者が用いた KLH 抗原 とした LAI 試䝠仙 非特異的な兔疫反応といえる。しか

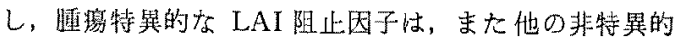
な负度反応の抑制活性を持つとされる報告もある477. 区 応系が常に一定得られる点から，KLHを抗原とした LAI 試毺は，担癌患者血清中 LAI 阻止因子の検出法と して合理的かつ有用等方法と考光る。

\section{LAI 阻止因子と先疫被合体}

前述のごとく，LAI 阻止因子と免疫裸合体とは深く 関逜すると報告されている 々の疾腎，病態にて血清中に出現することが認められて

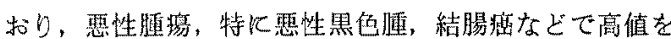
示すとされている，病期の進行ととむに上昇を示す場合 もあり，予後との関連性も報告されている ${ }^{183}$ ．著者は LAI 試驗，LAI 阻止因子と関連するパラメーターを㛟

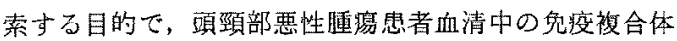
を，抗 C3 固相 ELISA 法用いて 測定した. 今国の成

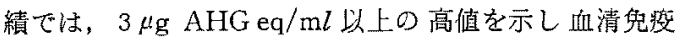
複合体晹性と考克た症例怯，喉頭癌症例で $20.7 \%$ ，上

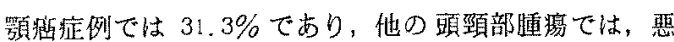
性リンパ腫，上咽頭癌とも飞低い陽性率であった，㘈頭

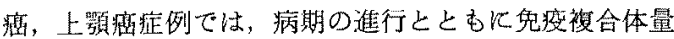
屯上䄯の傾向がみられ，従来の他領域の報告と一致す る. LAI 阻止因子との関連をみると，LAI 阻止因子の 出現，消退と免度複合体の值は，同様の变動を示すこと

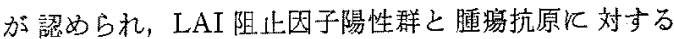
LAI 試駼陽性群では，LAI 阻止因子陽性群の兔疫複合 体量は有意飞高值を示し，陽性率の比較でも，LAI 阻止

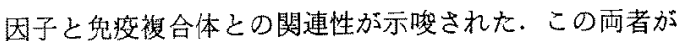
同一因子である上する報告もあるが俑，今回の結果から

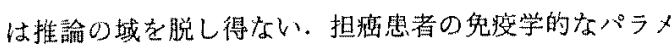
一ターとして，CEAを同時に測定したが，CEA とLAI 阻止因子との関連性牥認められなかった。

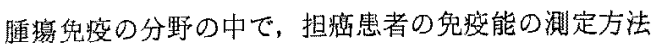
として LAI 試験はいまだ解決しなくてはならない問題 点老残すむのの，担癌生体の抗腫瘍兔疫能の測定と，そ の免疫能を抑制する因子の測定という異なる二つの免疫 
動態を同様の方法にて簡便に測定できる有用な手段とい

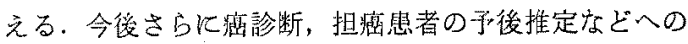
応用の可能性を追及する必要があると考光る。

\section{ま と め}

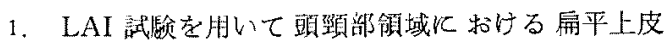

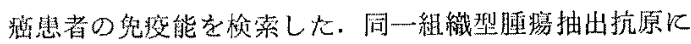

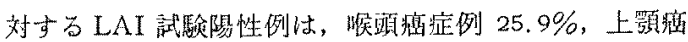
症例 $33.3 \%$ kみられ，付着指数柱，対照，良性疾㭧群 比此高值走した。

2. 臨本病期の進行とともに LAI 訊験隄性率は低下 傾向を示した。

3. KLH 抗原とし, KLH 感作单核細胞V LAI 反 応の招こることがマウス，ヒトそれぞれに認められた。

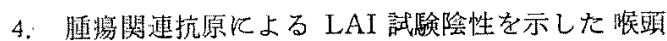

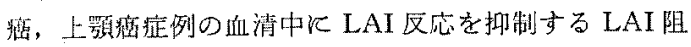
止因子の山現認めた。阻止因子の检出は，KLH を抗

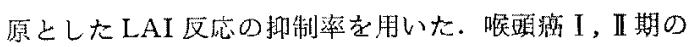
症例では，LAI 阻止因子陽性率は０\%であり，㘈鳆，

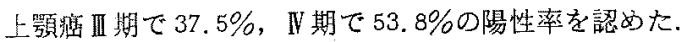
病期の進行飞徒いLAI 阻止因子の陽性率は上昇傾向を 認めた。

5. 頭频部悪性腫堭患者血清中の免疫被合体を 抗 C3 固相 ELISA 法飞て測定し，LAI 阻止因子との関連を检 討した，血清免疫裸合体陽性率は，啒頭癌症例で 20.7

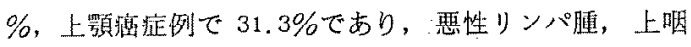

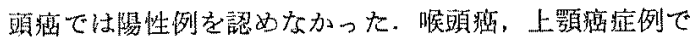
は病期の進行とと屯に兔疫被合体量は上显傾向を示し た。 LAI 阻止因子陽珄例では，筧疫䙡合体量が高值を 示し，阻止因子陰性例䎲比し有意の差を認めた。また臨 床経過淿て両者は同様の変動を示すことが多く，両者の 関逜性が示焧された。

\section{参考文 献}

1) Halliday WJ and Miller S: Leukocyte adherence inhibition: A simple test for cell mediated tumor immunity and serum blocking factor. Int $\mathrm{J}$ Cancer 9: 477-483, 1972.

2) Holan $V$, Sibl $O$ and Hasek $M$ : Monitoring of anti-tumor immunity in patients with larynx cancer by tube leukocyte adherence inhibition assay. Cancer Res 39:651-653, 1979.

3) Hasek M, Holan V, Sibl O et al: Application of tube LAI assay in larynx cancer patients. Neoplasma 28: 685-689, 1981.

4) Vetto RM, Burger DR, Vandenbark AA et al: Changes in tumor immunity during therapy determined by leukocyte adherence inhibition and dermal testing. Cancer 41:1034-1039, 1978.

5）由判俊平 管原利夫村松智弘藤田訓也 作田正

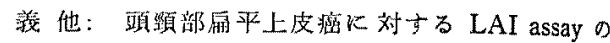
就断的価値 日本憈治療学会報 15：339-346，1980.

6) Halliday WJ, Maluish $\mathrm{A}$ and Isbister $\mathrm{WH}$; detection of anti-tumor cell mediated immunity and serum blocking factor in cancer patients by leukocyte adherence inhibition test. Brit J Cancer 29: 31-35, 1974.

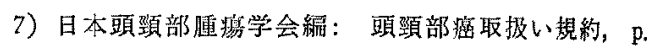
57-81，金原出烦，1982.

8) Lowry $\mathrm{OH}$, Rosebrough NJ, Farr AC et al: Protein measurement with the Folin phenol reagent. J Biol Chem 193: 265-275, 1951.

9) Yonemoto RH: Clinical application in breast cancer assessment of immune status by the leukocyte adherence inhibition test (edited by Thomson DMP): p. 98-101, Academic Press, New York. 1982.

10) Grosser $N$ and Thomson DMP: Cell mediated anti-tumor immunity in breast cancer patients evaluated by antigen induced leukocyte adherence inhibition in test tube. Cancer Res 35: 2571$2579,1975$.

11) Garvey JS: Method in immunology, 3rd edition (edited by Garvey JS et al): p. 135-139, The Benjamin/Cummings, Massachusetts, 1977.

12）奥田正治 西戸孝昭 宮坂信之: 新耴な㜊延型 7 V ルギー皮内反応，とくK PHA 反応と KLH反応 医学のあゆみ 102：8-12, 1977.

13) Pereira $A B$, Theofilopoulos $A N$ and Dixon FJ: Detection and partial characterization of circulating immune complexes with solid-phase antiC3. J Immunol 125: 763-770, 1980.

16) Bradford $M$ : A rapid and sensitive method for the quantitation of microgram quantities of protein utilizing the principle of protein-dye binding. Anal Biochem 72: 248-254, 1976. 
15）内田幸男松崎広子：CEA「ロシュ」-EIA キット

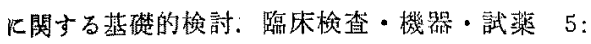
$597-601,1981$.

16) Lundy J, Wanebo $\mathrm{H}$, Pinky $\mathrm{C}$ et al: Delayed hypresensitivity reactions in patients with squamous cell cancer of the head and neck. Am J Surg 128: 530-533, 1974.

17) Parker $R$, Alexander $S$, Shabeen $O H$ et al: On the immunology of head and neck cancer. J Laryngol Otol 89: 687-695, 1975.

18) Mason JM, Kitchens GG, Easthan RJ et al: $T$ lymphocytes and survival of head and neck squamous cell carcinoma. Arch Otolaryngol 103: 223-227, 1977.

19) Flores $M$, Marti $J H$, Grosser $N$ et al: An overview: Anti-tumor immunity in breast cancer assayed by tube leukocyte adherence inhibition. Cancer 39: 494-505, 1977.

20) Urist MM, Boddie AW Jr, Holmes EC et al: Capplary tube leukocyte adherence: An assay for cell mediated immunity in cancer patients. Int J Cancer 17: 338-341, 1976.

21). Macfarlane JK, Thomson DMP, Phelan $K$ et al: Predictive value of tube leukocyte adherence inhibition (LAI) assay for breast, colorectal, stomach and pancreatic cancer. Cancer 49: 1185$1193,1982$.

22) Goldrosen $\mathrm{MH}$, Howell JH and Holyoke ED: Demonstration of the microtest version of the leukocyte adherence inhibition assay. Cancer Res 39: 630-632, 1979.

23) Goldrosen NH: Demonstration and evaluation of leukocyte adherence inhibition assay. Cancer Res 39: 624, 1979.

24) Schimke R, Holan V, Sibl O et al: Comparison of the hemocytemeter and tube modifications of the leukocyte adherence inhibition assay; II Application of the both modifications for detection of anti-tumor immunity in man. Neoplasma 28: 257-264, 1981 .

25) Halliday WJ: Histological background and aspects of the mechanism of leukocyte adherence inhibition. Cancer Res 39: 558-563, 1979.
26) Thomson DMP and Grosser N: Immunological mechanisms of tube leukocyte adherence inhibition. Cancer Res 39: 576-581, 1979.

27) Myers W, Okeefe ML and Gregory S: Lymphoid source and target of murine leukocyte adherence inhibition factor (LAIF). Immunol Letter 3 : 277-282, 1982.

28) Koppi TA and Halliday WJ: Further characterization of the cells involved in leukocyte adherence inhibition with murine tumor extracts. Cell Immunol 66: 394-406, 1982.

29) Powell AE, Birch RE, Murrell $\mathrm{H}$ et al: Cell population in leukocyte adherence inhibition: Requirement for $T$ lymphocytes with IgG $F_{c}$ re. ceptors. Immunol 46: 689-696, 1982.

30) Taylor SG, Saffold PC, :Braun DP et:al: $T_{\sigma}$ cell involment in the leukocyte adherence inhibition phenomenon. JNCI 68: 549-554, 1982.

31) Powell AE: Assessment of immune status by the leukocyte adherence inhibition test (edited by Thomson DMP) p. 44-48, Academic Press, New York, 1982.

32) Kaneti J, Thomson DMP and Reid EC: ' Pro. staglandin $\mathrm{E} 2$ affects the tumor immune response in prostatic carcinoma. J Urol 126: 65-70, 1981.

33) Kotlar HK, Eker P, Brennhord I et al: Leukocyte adherence inhibition assay in pulmonary neoplasia. Eur J Cancer Clin Oncol 18: 141146,1982 .

34) Machida S, Yamauchi M, Sato $M$ et al: An evaluation of LAI microassay using colorectal cancer cell line. Gann 71: 387-392, 1980.

35) Sanner T, Kotlor HKR and Eker P: Immune responses in lung cancer patients measured by a modified leukocyte adherence inhibition test using serum. Cancer Letters 8; 283-290, 1980.

36) Appelboom $T$, Govaerts $A$ and Wybran $J$ : Leukocyte adherence inhibition test in arthritis. Lancet July 8: 62-65, 1978.

37）松本美富士 江口敬子：全身性エリテマトーデス (SLE) 想者における Leukocyte Adherence in- 
hibition (LAI) 乖験の検討 アレルギー 29:187$193,1980$.

38）松本美富士 江口喊子 加藤芳郎：薬物アレルギー 急者に晾ける Leukocyte Adherence Inhibition (LAI) 試娩の応用 臨休危疫 13：329-395，1981。

39) Angers JW, Korik I, Franklin LS et al: The leukocyte adherence inhibition assay as a diagnostic test for multiple sclerosis. J Lab Clin Med 93: 528-534, 1978.

40) Bullen AW and Loswsky MS: Comparison of a leukocyte adherence inhibition test with the leukocyte migration inhibition test and skin reactivity to PPD. Clin Exp Immunol 31: 408$413,1978$.

41) Koppi TA, Maluish AE and Halliday WJ: The cellular mechanism of leukocyte adherence inhibition. J Immunol 123: 2255-2260, 1979.

42) Holt PG, Fimmel PJ, Finlay-Jones LM et al: Evaluation of the microplate leukocyte adherence inhibition test and its reprodicibility, sensitivity and relationship to other tests of cellular immunity.: Cancer Res 39: 564-569, 1979.

43) Goldrosen MH, Dasmahapatra $K$, Jenkins $D$ et al: Micropiate leukocyte adherence inhibition assay in pancreatic cancer. Detection of specific anti-tumor immunity with patients' peripheral blood cells and serum. Cancer 47: 16!4-1619, 1981.

44) Thomson DMP, Tataryn DN, Schwartz R et al: Abrogation of the phenomenon of leukocyte ad- herence inhibition by excess circulating tumor antigen. Eur J Cancer 15: 1095-1106, 1979.

45) Raina S, Russo AJ, Jenkins D et al: Role of $T$ cells in the mechanism of reactivity of the microplate leukocyte adherence inhibition assay. Cancer Res 41: 3950-3955, 1981.

46) Koppi TA, Halliday WJ and McKenzie IFC: Regulation of cell-mediated immunologic reactivity to Moloney murine sarcoma virus-induced tumors.: II Nature of blocking and unblocking factors in serum. JNCI 66: 1097-1102, 1981 ,

47) Tanaka F, Yonemoto RH and Waidman SR: Blocking factor in sera of breast cancer patients. Cancer 43: 838-847, 1979.

48) Theofilopoulos AN, Wilson $\mathrm{CB}$ and Dixon FJ: The Raji cell radioimmunoassay for detecting immune complexes in human sera. J Clin Invest 57: $169-182,1976$.

稿を終えるにあたり，ご指導，こ校閲下さいました札

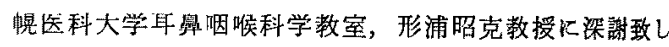
ます、またこ校閲を晹わりました第一病理学教室, 菊地 浩吉教授に心より感謝の意を表します：直接ご指真頂い た，山中年满師に感謝の意を表すととるに，教室具の請 兄のご協力に感謝致します。

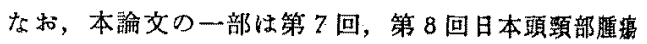
学会に数いて器表した。

（原稿受付 昭和 59.9.17日)

別刷請求先 $\overline{0} 060$ 札沅市中央区南 1 条西16丁目 札幌医科大学耳鼻咽喉科学教室 米見 徽夫 